\title{
Chlorine isotope composition in chlorofluorocarbons CFC-11, CFC-12 and CFC-113 in firn, stratospheric and tropospheric air
}

\author{
S. J. Allin ${ }^{1}$, J. C. Laube ${ }^{1}$, E. Witrant ${ }^{2}$, J. Kaiser ${ }^{1}$, E. McKenna ${ }^{1}$, P. Dennis ${ }^{1}$, R. Mulvaney ${ }^{3}$, E. Capron ${ }^{3}$, P. Martinerie ${ }^{4}$, \\ T. Röckmann ${ }^{5}$, T. Blunier ${ }^{6}$, J. Schwander ${ }^{7}$, P. J. Fraser ${ }^{8}$, R. L. Langenfelds ${ }^{8}$, and W. T. Sturges ${ }^{1}$ \\ ${ }^{1}$ Centre for Ocean and Atmospheric Sciences, School of Environmental Sciences, University of East Anglia, Norwich, UK \\ ${ }^{2}$ Grenoble Image Parole Signal Automatique, Université Joseph Fourier/CNRS, Grenoble, France \\ ${ }^{3}$ British Antarctic Survey, Natural Environment Research Council, Cambridge, UK \\ ${ }^{4}$ CNRS/Univ. Grenoble Alpes, 38041, Grenoble, France \\ ${ }^{5}$ Institute for Marine and Atmospheric Research Utrecht, Utrecht University, Utrecht, the Netherlands \\ ${ }^{6}$ Centre for Ice and Climate, University of Copenhagen, Copenhagen, Denmark \\ ${ }^{7}$ Physics Institute, University of Bern, Bern, Switzerland \\ ${ }^{8}$ Centre for Australian Weather and Climate Research, Oceans and Atmosphere Flagship, Commonwealth Scientific and \\ Industrial Research Organisation, Aspendale, Australia
}

Correspondence to: S. J. Allin (s.allin@uea.ac.uk)

Received: 11 November 2014 - Published in Atmos. Chem. Phys. Discuss.: 17 December 2014

Revised: 13 May 2015 - Accepted: 03 June 2015 - Published: 23 June 2015

\begin{abstract}
The stratospheric degradation of chlorofluorocarbons (CFCs) releases chlorine, which is a major contributor to the destruction of stratospheric ozone $\left(\mathrm{O}_{3}\right)$. A recent study reported strong chlorine isotope fractionation during the breakdown of the most abundant CFC (CFC-12, $\mathrm{CCl}_{2} \mathrm{~F}_{2}$, Laube et al., 2010a), similar to effects seen in nitrous oxide $\left(\mathrm{N}_{2} \mathrm{O}\right)$. Using air archives to obtain a longterm record of chlorine isotope ratios in CFCs could help to identify and quantify their sources and sinks. We analyse the three most abundant $\mathrm{CFCs}$ and show that CFC$11\left(\mathrm{CCl}_{3} \mathrm{~F}\right)$ and $\mathrm{CFC}-113\left(\mathrm{CClF}_{2} \mathrm{CCl}_{2} \mathrm{~F}\right)$ exhibit significant stratospheric chlorine isotope fractionation, in common with CFC-12. The apparent isotope fractionation $\left(\varepsilon_{\mathrm{app}}\right)$ for midand high-latitude stratospheric samples are respectively -2.4 (0.5) and $-2.3(0.4) \%$ for CFC-11, -12.2 (1.6) and -6.8 (0.8)\%o for CFC-12 and -3.5 (1.5) and $-3.3(1.2) \%$ for CFC-113, where the number in parentheses is the numerical value of the standard uncertainty expressed in per mil. Assuming a constant isotope composition of emissions, we calculate the expected trends in the tropospheric isotope signature of these gases based on their stratospheric ${ }^{37} \mathrm{Cl}$ enrichment and stratosphere-troposphere exchange. We compare these projections to the long-term $\delta\left({ }^{37} \mathrm{Cl}\right)$ trends of all three CFCs, measured on background tropospheric sam-
\end{abstract}

ples from the Cape Grim air archive (Tasmania, 1978-2010) and tropospheric firn air samples from Greenland (North Greenland Eemian Ice Drilling (NEEM) site) and Antarctica (Fletcher Promontory site). From 1970 to the present day, projected trends agree with tropospheric measurements, suggesting that within analytical uncertainties, a constant average emission isotope delta $(\delta)$ is a compatible scenario. The measurement uncertainty is too high to determine whether the average emission isotope $\delta$ has been affected by changes in CFC manufacturing processes or not. Our study increases the suite of trace gases amenable to direct isotope ratio measurements in small air volumes (approximately $200 \mathrm{~mL}$ ), using a single-detector gas chromatography-mass spectrometry (GC-MS) system.

\section{Introduction}

CFC-11 $\left(\mathrm{CCl}_{3} \mathrm{~F}\right), \quad \mathrm{CFC}-12 \quad\left(\mathrm{CCl}_{2} \mathrm{~F}_{2}\right)$ and $\mathrm{CFC}-113$ $\left(\mathrm{CClF}_{2} \mathrm{CCl}_{2} \mathrm{~F}\right)$ are the most abundant chlorofluorocarbons (CFCs) in the atmosphere (Table 1). They are very stable and are not flammable or toxic, making them suitable as refrigerants, aerosol propellants and foam blowing agents. Measurements performed on air from porous firn (the 
Table 1. Key atmospheric characteristics of CFC-11, CFC-12 and CFC-113.

\begin{tabular}{|c|c|c|c|}
\hline & \multicolumn{3}{|c|}{ Compound } \\
\hline & CFC-11 & CFC-12 & CFC-113 \\
\hline a 2009 mole fraction $/ \mathrm{pmol} \mathrm{mol}^{-1}$ & 243 & 535 & 76 \\
\hline b Atmospheric lifetime/years & 52 & 102 & 93 \\
\hline${ }^{\mathrm{a}}$ Ozone depletion potential (ODP) & 1 & 0.82 & 0.85 \\
\hline
\end{tabular}

a NOAA/AGAGE mean values taken from Montzka et al. (2011) and ${ }^{\mathrm{b}}$ data from SPARC (2013).

top part of the polar ice sheet consisting of consolidated snow, progressively transforming into ice) show that they were absent from the atmosphere before the middle of the 20th century (e.g. Butler et al., 1999; Sturrock et al., 2002; Buizert et al., 2012). This suggests that they have no natural sources. CFC-11, CFC-12 and CFC-113 first appeared in the mid-1900s (Sturrock et al., 2002; Martinerie et al., 2009), which coincides with the start of their widespread anthropogenic production and consumption.

Atmospheric removal occurs in the stratosphere, where sink processes are dominated by photodissociation (Reaction $\mathrm{R} 1$ ) and reaction with $\mathrm{O}\left({ }^{1} \mathrm{D}\right)$ (Reaction $\left.\mathrm{R} 2\right)$, i.e.

$$
\begin{aligned}
& \mathrm{CCl}_{2} \mathrm{~F}_{2}+h v \rightarrow \mathrm{CClF}_{2}+\mathrm{Cl}, \\
& \mathrm{CCl}_{2} \mathrm{~F}_{2}+\mathrm{O}\left({ }^{1} \mathrm{D}\right) \rightarrow \mathrm{CClF}_{2}+\mathrm{ClO} .
\end{aligned}
$$

$\mathrm{Cl}$ and $\mathrm{ClO}$ released in these reactions catalyse the destruction of $\mathrm{O}_{3}$ (Molina and Rowland, 1974). Following the identification of a strong decrease in $\mathrm{O}_{3}$ over Antarctica (Farman et al., 1985), swift international action worked to phase-out the production and consumption of CFCs under the Montreal Protocol and its subsequent amendments.

Measuring isotope ratios in atmospheric trace gases provides additional information regarding their sources and sinks as well as the ways in which they contribute to biogeochemical cycles (Brenninkmeijer et al., 2003; Goldstein and Shaw, 2003). Long-term studies have investigated a range of species, for example, $\mathrm{CH}_{4}$ (Etheridge et al., 1998), $\mathrm{CO}_{2}$ (Francey et al., 1999; Rubino et al., 2013) and $\mathrm{N}_{2} \mathrm{O}$ (Röckmann et al., 2003; Kaiser et al., 2006).

Of particular relevance to this work is $\mathrm{N}_{2} \mathrm{O}$, a muchstudied gas with similar sinks and a comparable lifetime to CFC-12. Various studies have used firn and ice core samples (Sowers et al., 2002; Röckmann et al., 2003; Bernard et al., 2006; Ishijima et al., 2007) as well as direct atmospheric samples (Yoshida and Toyoda, 2000; Kaiser et al., 2006) to investigate large-scale $\mathrm{N}_{2} \mathrm{O}$ isotope and abundance changes. Source inputs depleted in ${ }^{15} \mathrm{~N}$ and ${ }^{18} \mathrm{O}$ are thought to have caused the concurrent tropospheric $\mathrm{N}_{2} \mathrm{O}$ abundance increase and $\delta\left({ }^{15} \mathrm{~N}\right)$ and $\delta\left({ }^{18} \mathrm{O}\right)$ decrease over the last century, while sink processes enrich stratospheric $\mathrm{N}_{2} \mathrm{O}$ in heavy isotopes (Röckmann et al., 2003). Altitude and latitude dependence has also been observed, with the isotopic fractionation $(\varepsilon)$ increasing with altitude and as the sampling point moves to- wards the equator (Kaiser et al., 2006). Firn air studies are limited in their temporal resolution because diffusion processes smooth interannual and seasonal variations. Direct atmospheric air samples have been used to study these shorterscale changes (Nevison et al., 2005, 2011; Röckmann and Levin, 2005; Park et al., 2012). The seasonality observed in isotope and mole fraction measurements has not been fully explained, but a potential contributor is the movement of $\mathrm{N}_{2} \mathrm{O}$-depleted air with a correspondingly enriched isotopic composition from the stratosphere to the surface (Park et al., 2012).

In contrast to $\mathrm{N}_{2} \mathrm{O}, \mathrm{CFCs}$, which are much less abundant, are poorly characterised because very few studies have investigated their isotope ratios. Redeker et al. (2007) measured tropospheric $\delta\left({ }^{13} \mathrm{C}\right)$ values for 37 hydrocarbons and halocarbons, including CFC-11, CFC-12 and CFC-113, over the course of a year. They found no diurnal or seasonal trends outside their analytical uncertainties. Zuiderweg et al. (2012) measured the stable carbon isotope fractionation of CFC-11 and CFC-12 by simulating stratospheric conditions during UV photolysis experiments. They found a fractionation $(\varepsilon)$ of $-23.0 \%$ for CFC-11, compared to $-55.3 \%$ o for CFC-12 (at $233 \mathrm{~K})$. Zuiderweg et al. (2013) measured $\delta\left({ }^{13} \mathrm{C}, \mathrm{CFC}-12\right)$ on North Greenland Eemian Ice Drilling (NEEM) firn air and reported a relative ${ }^{13} \mathrm{C} /{ }^{12} \mathrm{C}$ enrichment of up to $80 \%$ from 1950 to the present day.

The only chlorine isotope ratio study of atmospheric CFCs measured the $\delta\left({ }^{37} \mathrm{Cl}\right)$ of CFC-12 in the tropical stratosphere (Laube et al., 2010a). Enrichment with altitude, to a maximum of $27 \%$, was attributed to sink reactions (Reactions R1 and R2) occurring more readily with the lighter isotopologue. Assuming a Rayleigh-type fractionation mechanism, the apparent stratospheric isotope fractionation $\left(\varepsilon_{\mathrm{app}}\right)$ was calculated to be -12.1 (1.7)\%o. Laube et al. (2010a) highlighted the large effect of sink reactions on the isotopic composition of CFC-12 in the stratosphere. It is expected that this will lead to a relative ${ }^{37} \mathrm{Cl}$ enrichment of tropospheric $\mathrm{CFC}$ 12 with respect to the average source isotope ratio through stratosphere-troposphere air exchange, similar to observations made on other gases, such as $\mathrm{CH}_{4}$ (McCarthy et al., 2001), $\mathrm{H}_{2}$ (Batenburg et al., 2012) and $\mathrm{N}_{2} \mathrm{O}$ (Röckmann et al., 2003).

The strong stratospheric chlorine isotope fractionation of CFC-12 (Laube et al., 2010a) and the substantial change inferred from $\delta\left({ }^{13} \mathrm{C}\right)$ measurements (Zuiderweg at al., 2013) motivated us to conduct a more complete investigation of the chlorine isotope history of this species. This type of study has the potential to better constrain global sources and sinks (Röckmann et al., 2003). Here we use new measurements on stratospheric samples to quantify the apparent stratospheric ${ }^{37} \mathrm{Cl} /{ }^{35} \mathrm{Cl}$ isotope fractionation $\left(\varepsilon_{\text {app }}\right)$ of chlorine not only in CFC-12, but also in CFC-11 and CFC-113. Alongside these values, stratosphere-troposphere exchange estimates are used to predict the tropospheric chlorine isotope history of these species. We then present new tropospheric measure- 
Table 2. Details of the samples used in this study.

\begin{tabular}{lllll}
\hline Sample type & Sampling location & Sampling dates & $\begin{array}{l}\text { Ca. year of } \\
\text { origin }\end{array}$ & Further details \\
\hline Free tropospheric air & $\begin{array}{l}\text { Cape Grim, } \\
\text { Tasmania }\end{array}$ & $1978-2010$ & $1978-2010$ & $\begin{array}{l}\text { Sampling procedure previously re- } \\
\text { ported } \\
\text { (e.g Langenfelds et al., } \\
\text { 1996) }\end{array}$ \\
\hline Tropospheric firn air & $\begin{array}{l}\text { Fletcher Promontory, } \\
\text { Antarctica }\end{array}$ & January 2012 & 1970-2012 & $\begin{array}{l}\text { Drilling and firn air pumping op- } \\
\text { erations conducted by the British } \\
\text { Antarctic Survey }\end{array}$ \\
\hline Tropospheric firn air & Northern Greenland & July 2009 & $1950-2009$ & $\begin{array}{l}\text { Drilling and firn air pumping oper- } \\
\text { ations during the NEEM field cam- } \\
\text { paign }\end{array}$ \\
\hline Stratospheric air & $\begin{array}{l}\text { Mid-latitude samples } \\
\left(48.1-53.4^{\circ}\right)\end{array}$ & 2009 & - & $\begin{array}{l}\text { M55 Geophysica research aircraft, } \\
\text { take } \\
\text { off from Oberpfaffenhofen, } \\
\text { Germany }\end{array}$ \\
\hline Stratospheric air & $\begin{array}{l}\text { High-latitude samples } \\
\left(66.3-76.2^{\circ}\right)\end{array}$ & 2010 & - & $\begin{array}{l}\text { M55 Geophysica research aircraft, } \\
\text { take off from Kiruna, Sweden }\end{array}$ \\
\hline
\end{tabular}

ments on samples from the Cape Grim air archive, as well as firn air from NEEM and Fletcher Promontory. These are compared to the model projections, leading to an evaluation of long-term chlorine isotope ratio changes in the three most abundant CFCs.

\section{Methodology}

Table 2 gives details of the samples used in this study (further details can be found in Tables S5-S9 in the Supplement). Mid- and high-latitude stratospheric air was collected on an M55 Geophysica research aircraft, as part of the European Union's FP7 project RECONCILE (von Hobe et al., 2013). Background tropospheric samples were sourced from Cape Grim (Tasmania) and firn air was sampled at the NEEM field campaign and Fletcher Promontory.

Firn air was recovered from the NEEM ice core site in Greenland (NEEM Community Members, 2013) and from the Fletcher Promontory ice core site in Antarctica (Mulvaney et al., 2014). In each case, shallow ice core drills progressively penetrated the firn column, stopping every few metres to allow recovery of the firn air. The firn air extraction technique (Schwander et al., 1993) uses a bladder inflated at the bottom of the borehole to seal off ambient air from above. Gas pumps draw sample air from the firn surrounding the lowest level of the borehole through continuous Dekabon tubes (internal diameter 1/4 in.) passing through the bladder and its end caps, compressing the air into sample flasks at the surface. An infrared analyser (LI-COR LI-7000) continuously monitors the sample line $\mathrm{CO}_{2}$ and samples are only taken when the $\mathrm{CO}_{2}$ drops to a stable reading lower than modern ambient levels, indicating that uncontaminated air is being extracted from the borehole.

\subsection{Sample preparation and analysis}

A gas chromatography-mass spectrometry (GC-MS) system, designed to make high precision measurements of pmol mol ${ }^{-1}$ level compounds in small air samples, was used for this work. A pre-concentration system with an Agilent 6890 GC was coupled to a VG/Waters EBE tri-sector mass spectrometer. Details of previous work conducted using this system can be found in Laube et al. (2010b) and Sturges et al. (2012).

Magnesium perchlorate $\left(\mathrm{Mg}\left(\mathrm{ClO}_{4}\right)_{2}\right)$ was used to dry the air introduced to the GC-MS system. Trace gases from $0.2 \mathrm{~L}$ (293 K, 1 bar) of air were pre-concentrated on Hayesep D (80/100 mesh), which was cooled to $-78^{\circ} \mathrm{C}$ by immersion in a dry ice/ethanol mixture. The sample was then trapped on a $49 \mathrm{~m}$ GS-GasPro column (internal diameter $0.32 \mathrm{~mm}$ ) at $-10^{\circ} \mathrm{C}$ for $2 \mathrm{~min}$. Heating to $200^{\circ} \mathrm{C}$ at $10^{\circ} \mathrm{C} \mathrm{min}^{-1}$ released the trapped compounds to the MS according to their retention strength.

The MS was operated in EI-SIR (electron impactselected ion recording) mode at a mass resolution of 1000. The fragment ions measured were $\mathrm{C}\left({ }^{35} \mathrm{Cl}\right)_{2} \mathrm{~F}^{+}(\mathrm{m} / z 101)$, $\mathrm{C}^{35} \mathrm{Cl}^{37} \mathrm{ClF}^{+}(m / z 103)$ and $\mathrm{C}\left({ }^{37} \mathrm{Cl}\right)_{2} \mathrm{~F}^{+}(m / z 105)$.

\subsection{Data processing}

In this study, isotope deltas $(\delta)$, expressed in per mill $(\% o)$, are used to denote the relative ${ }^{37} \mathrm{Cl} /{ }^{35} \mathrm{Cl}$ ratio difference of CFCs in sample air with respect to a standard,

$\delta\left({ }^{37} \mathrm{Cl}\right)=\frac{R_{\text {sample }}}{R_{\text {standard }}}-1$,

where $R$ represents the ${ }^{37} \mathrm{Cl} /{ }^{35} \mathrm{Cl}$ abundance ratio of a standard or sample. There is no internationally recognised iso- 
tope standard for these measurements. For this reason, all $\delta$ values in this study are relative to a laboratory standard (AAL-071170). This is a background air sample collected in 2006 at Niwot Ridge, Colorado, by the National Oceanic and Atmospheric Administration (NOAA).

This study considers isotopologue current ratios of the $\mathrm{CCl}_{2} \mathrm{~F}^{+}$fragment, rather than directly measuring $\mathrm{Cl}^{+}$ions. Equation (2) describes how the $\left.\mathrm{C}^{35} \mathrm{Cl}\right)_{2} \mathrm{~F}^{+}(\mathrm{m} / z 101)$, $\mathrm{C}^{35} \mathrm{Cl}^{37} \mathrm{ClF}^{+}(m / z 103)$ and $\mathrm{C}^{37} \mathrm{Cl}_{2} \mathrm{~F}^{+}(m / z, 105)$ fragments can be used to calculate the ${ }^{37} \mathrm{Cl} /{ }^{35} \mathrm{Cl}$ isotope ratio from the $\mathrm{CCl}_{2} \mathrm{~F}$ measurements,

$R=\frac{A\left({ }^{37} \mathrm{Cl}\right)}{A\left({ }^{35} \mathrm{Cl}\right)}=\frac{\frac{A\left(\mathrm{C}^{35} \mathrm{C}^{37} \mathrm{ClF}^{+}\right)}{A\left(\mathrm{C}^{35} \mathrm{Cl}_{2} \mathrm{~F}^{+}\right)}+2 \frac{A\left(\mathrm{C}^{37} \mathrm{Cl}_{2} \mathrm{~F}^{+}\right)}{A\left(\mathrm{C}^{35} \mathrm{Cl}_{2} \mathrm{~F}^{+}\right)}}{2+\frac{A\left(\mathrm{C}^{35} \mathrm{Cl}^{37} \mathrm{Cl}^{+}\right)}{A\left(\mathrm{C}^{35} \mathrm{Cl}_{2} \mathrm{~F}^{+}\right)}}$,

where $A$ represents the abundance of a given fragment. The $\mathrm{C}\left({ }^{37} \mathrm{Cl}\right)_{2} \mathrm{~F}^{+}$fragment was included in the analysis of 172 out of 448 samples. In all cases, $\delta$ values calculated using ratios derived from Eq. (2) agreed within $1 \sigma$ with $\delta$ values calculated directly from $\mathrm{C}^{35} \mathrm{Cl}^{37} \mathrm{ClF}^{+} / \mathrm{C}\left({ }^{35} \mathrm{Cl}_{2} \mathrm{~F}^{+}\right.$ratios (without the inclusion of the $\mathrm{C}\left({ }^{37} \mathrm{Cl}\right)_{2} \mathrm{~F}^{+}$fragment). We use the linear regression slope of the $\mathrm{C}^{35} \mathrm{Cl}^{37} \mathrm{ClF}^{+}$against the $\left.\mathrm{C}^{35} \mathrm{Cl}\right)_{2} \mathrm{~F}^{+}$ion current over the duration of the peak to derive $R$ and, based on this, $\delta$ (Eq. 1). Typically, two sample measurements were made between standard runs, allowing instrumental drift to be quantified and corrected for.

No chromatographic interferences were found for these ions at the retention times corresponding to CFC- 11 and CFC-12. However, CFC-113a has grown to a current atmospheric abundance of $\sim 0.5 \mathrm{pmol} \mathrm{mol}^{-1}$ since its emergence in the 1960s (Laube et al., 2014) and partially co-elutes with CFC-113. Interference from CFC-113a can be detected above the surrounding noise in one sample. This peak was manually excluded from the linear regression slope and a $\delta$ value calculated using Eq. (1). Within $1 \sigma$, this value is the same as the original $\delta$ value calculated, without removing the CFC-113a interference.

Poor-quality measurements were defined as a measurement with an $R_{\text {sample }}$ standard deviation (from repeat measurements) of more than 3 times the average standard deviation of the $R_{\text {standard }}$ values during an analysis period. Less than $1 \%$ of the measurements were rejected as poor quality. Measurements were also rejected if there was uncertainty regarding the integrity of the sample; small system leaks can be identified through the analysis of other trace compounds (e.g. sulfur hexafluoride, $\mathrm{SF}_{6}$ ). Two percent were excluded due to a suspected lack of sample integrity.

A static dilution series was prepared by diluting background air with research-grade nitrogen. These samples were used to quantify the response behaviour of the analytical system. Nonlinear isotope ratio responses were found at small mole fractions and were corrected (details in the Supplement). Ninety-nine percent of the measurements were unaffected by this nonlinearity and did not have to be corrected.
The smallest peaks measured for each species define the effective detection limit for this study. One CFC-113 sample was below this limit and rejected.

The stratospheric samples were used to calculate $\varepsilon_{\text {app }}$ for each species. This was done by assuming a Rayleigh-type mechanism and applying this linear relationship to the data (Kaiser et al., 2006):

$\ln \left(1+\delta^{37} \mathrm{Cl}\right) \approx \varepsilon_{\mathrm{app}} \ln \left(\frac{y}{y_{\mathrm{T}}}\right)$,

where $y$ and $y_{\mathrm{T}}$ are the stratospheric and tropospheric mole fractions, respectively.

A statistical "bootstrap" analysis technique was used to determine $\varepsilon_{\text {app }}$ values and their uncertainties (Volk et al., 1997). In this technique, a data pool is created by describing each sample with three values (the measured $\delta$ value and this value $\pm 1 \sigma$ ). The bootstrap tool draws 500 random samplings from the complete stratospheric data pool (including the possibility of drawing the same value repeatedly) to produce an overall $\varepsilon_{\text {app }}$ value and a robust associated uncertainty range. Anomalous stratospheric samples were omitted using an iterative least squares method, reducing the $\varepsilon_{\text {app }}$ standard error in all cases. Any sample more than 2 times the standard error of the $\ln (1+\delta)$ estimate away from the linear regression of the Rayleigh fractionation plot was removed. This process was repeated until all data points fell within 2 times the standard error of the $\ln (1+\delta)$ estimate. Of the measurements, $21 \%$ (CFC-11), $10 \%$ (CFC-12) and $7 \%$ (CFC-113) were rejected using this method.

\subsection{Emissions and transport modelling}

Following Kaiser (2002) and Röckmann et al. (2003), a twobox model of the atmosphere is used to project the changing tropospheric isotope signature. The following mass balance equations hold for the model atmosphere, partitioned into a stratosphere (index S) and a troposphere/lowermost stratosphere (index T), where chemical loss only occurs in the stratosphere

$n_{\mathrm{T}} \frac{\mathrm{d} y_{\mathrm{T}}}{\mathrm{d} t}=E-F_{\mathrm{TS}}+F_{\mathrm{ST}}=E-F\left(y_{\mathrm{T}}-y_{\mathrm{S}}\right)$,

$n_{\mathrm{S}} \frac{\mathrm{d} y_{\mathrm{S}}}{\mathrm{d} t}=F_{\mathrm{TS}}-F_{\mathrm{ST}}-L=F\left(y_{\mathrm{T}}-y_{\mathrm{S}}\right)-J n_{\mathrm{S}} y_{\mathrm{S}}$.

The symbols have the following meaning: $n$ - amount of air (in mol), $y$ - mole fraction (in mol mol${ }^{-1}$ ), $F$ - bulk air flux between troposphere and stratosphere and vice versa (in mol a $\left.{ }^{-1}\right), F_{\mathrm{TS}}-\mathrm{CFC}$ flux from troposphere to stratosphere (in mol a $\left.{ }^{-1}\right), F_{\mathrm{ST}}-\mathrm{CFC}$ flux from stratosphere to troposphere (in mol a ${ }^{-1}$ ), $E$ - trace gas emissions (in $\mathrm{mol} \mathrm{a}^{-1}$ ), $L$ - trace gas loss (in mol a ${ }^{-1}$ ) and $J$ - loss rate coefficient (in $\mathrm{a}^{-1}$ ).

The global average lifetime is calculated as the ratio of total burden and total loss:

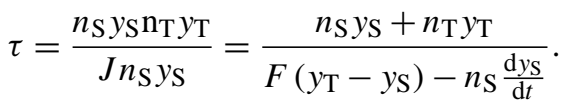


The parameters $n_{\mathrm{T}}, n_{\mathrm{S}}$ and $F$ are taken from Holton (1990), Trenberth and Guillemot (1994) and Appenzeller et al. (1996). Using the tropospheric mole fraction history $y_{\mathrm{T}}(t)$ (Velders and Daniel, 2014) and an estimate of the global average lifetime $\tau$, Eqs. (4), (5) and (6) can be solved for $y_{\mathrm{S}}$, $J$ and $E$. In practice, we adjust $J$ so that the average $\tau$ for the years 1999 to 2008 equals the lifetime estimates as per SPARC (2013), and we use a fixed value of $J$ for all model years.

To derive the corresponding isotope budget, we write Eqs. (4) and (5) for another isotopologue (primed quantities):

$n_{\mathrm{T}} \frac{\mathrm{d} y_{\mathrm{T}}^{\prime}}{\mathrm{d} t}=E^{\prime}-F\left(y_{\mathrm{T}}^{\prime}-y_{\mathrm{S}}^{\prime}\right)$,

which can be written in $\delta$ notation (relative to an arbitrary reference material). We have $y_{\mathrm{T}}^{\prime}=y_{\mathrm{T}}\left(1+\delta_{\mathrm{T}}\right) R_{\text {standard }}, y_{\mathrm{S}}^{\prime}=$ $y_{\mathrm{S}}\left(1+\delta_{\mathrm{S}}\right) R_{\text {standard }}$ and $y_{P}^{\prime}=y_{P}\left(1+\delta_{P}\right) R_{\text {standard }}$. Substituting this into Eq. (7) gives Eq. (8):

$$
\begin{aligned}
n_{\mathrm{T}} \frac{\mathrm{d}\left[y_{\mathrm{T}}\left(1+\delta_{\mathrm{T}}\right)\right]}{\mathrm{d} t} & =E\left(1+\delta_{E}\right) \\
& -F\left[y_{\mathrm{T}}\left(1+\delta_{\mathrm{T}}\right)-y_{\mathrm{S}}\left(1+\delta_{\mathrm{S}}\right)\right] .
\end{aligned}
$$

Together with Eq. (4) this gives the tropospheric isotope budget:

$n_{\mathrm{T}} y_{\mathrm{T}} \frac{\mathrm{d} \delta_{\mathrm{T}}}{\mathrm{d} t}=E\left(\delta_{E}-\delta_{\mathrm{T}}\right)+F y_{\mathrm{S}}\left(\delta_{\mathrm{S}}-\delta_{\mathrm{T}}\right)$.

The equivalent equation for the stratosphere is

$n_{\mathrm{S}} y_{\mathrm{S}} \frac{\mathrm{d} \delta_{\mathrm{S}}}{\mathrm{d} t}=F y_{\mathrm{T}}\left(\delta_{\mathrm{T}}-\delta_{\mathrm{S}}\right)-n_{\mathrm{S}} y_{\mathrm{S}} J \varepsilon_{J}\left(1+\delta_{\mathrm{S}}\right)$,

where the photochemical isotope fractionation is

$\varepsilon_{J}=\frac{J^{\prime}}{J}-1$,

with $J^{\prime}$ being the loss rate coefficient for the isotope in the numerator of the isotope ratio (here, ${ }^{37} \mathrm{Cl}$ ).

$\varepsilon_{J}$ (or $J^{\prime}$ ) are not known, so again following the analogue of $\mathrm{N}_{2} \mathrm{O}$ (Röckmann et al., 2003), we use the observed apparent Rayleigh isotope fractionation in the stratosphere $\left(\varepsilon_{\text {app }}\right)$, to solve the isotope-specific part of the budget. Based on this apparent Rayleigh isotope fractionation, the relative isotope ratio difference between the stratosphere and the troposphere $\delta_{\mathrm{ST}}$ can be calculated according to

$$
\begin{aligned}
\delta_{\mathrm{ST}} & =\frac{1+\delta_{\mathrm{S}}}{1+\delta_{\mathrm{T}}}-1=\frac{\delta_{\mathrm{S}}-\delta_{\mathrm{T}}}{1+\delta_{\mathrm{T}}}=\frac{-\delta_{\mathrm{TS}}}{1+\delta_{\mathrm{TS}}} \\
& =\left(\frac{y_{\mathrm{S}}}{y_{\mathrm{T}}}\right)^{\varepsilon_{\mathrm{app}}}-1 .
\end{aligned}
$$

$\varepsilon_{\text {app }}$ is the apparent stratospheric isotope fractionation, which is empirically determined for the years 1999 to 2008 (reflecting the time of stratospheric sample collection and the age of stratospheric air). It depends on both chemistry and transport (Kaiser et al., 2006), which may have changed over the period of CFC emissions. $\varepsilon_{J}$ is a model parameter that is tuned to give $\varepsilon_{\text {app }}$ for the corresponding model years. It has no immediate physical interpretation and is only meaningful in the context of the chosen two-box model. We adjust $\varepsilon_{J}$ so that the average $\varepsilon_{\text {app }}$ value for the years 1999 to 2008 equals our stratospheric observations and derive the projected atmospheric history of $\delta_{\mathrm{T}}$ and $\delta_{\mathrm{S}}$ from Eqs. (10) and (12), assuming a constant $\delta_{E}$ value that results in $\delta_{\mathrm{T}}(2006)=0$, corresponding to the year our tropospheric air standard was filled.

\subsection{Trace gas transport in firn}

The migration of gases from the atmosphere through firn is largely controlled by diffusional and gravitational effects, such that less diffusive gases move through the firn more slowly than more diffusive gases and heavier gases and isotopologues are enriched at depth relative to lighter gases and isotopologues. Consequently, there is no unique "age-of-air" at a given depth in the firn, rather an age distribution is calculated for a specific gas or isotopologue. Also, a gas can undergo significant isotope fractionation during its movement through the firn. A model of gas transport in firn must therefore include both diffusive transport and gravitational separation to reconstruct changes in atmospheric abundances and isotope ratios over time. These reconstructions have been accomplished here using the model developed at the Laboratoire de Glaciologie et Géophysique de l'Environnement (LGGE) and Grenoble Image Parole Signal Automatique (GISPA-lab). The physical basis of the model is described in Witrant et al. (2012). The model has been further refined to provide a new and more robust definition of the optimal solution, and a more rigorous treatment of isotopes based on a forward firn model written in terms of $\delta$ values (Witrant and Martinerie, 2013). The diffusive behaviour of gases is initialised for each firn column by using a set of gases with well-known atmospheric histories (Witrant et al., 2012).

More details on the firn modelling are given in the Supplement. The dates shown here for the firn data are based on median ages for each gas. The age spectrum associated with these median ages is also discussed in the Supplement. When plotting mole fractions and isotope $\delta$ against median age, it is necessary to correct for gravitational and diffusive fractionation. In the case of mole fractions, gravitational settling is calculated as the difference between normal model runs and runs in which gravity is set to zero. For within-firn isotope fractionation, a correction (of $1-2 \%$ ) is calculated using the reconstructed scenario of the gas mole fraction and assuming a constant atmospheric isotope $\delta$. After these corrections, any discrepancies between projected and measured firn isotope $\delta$ reflect changes in atmospheric isotope $\delta$ over time.

Thermal diffusion was not included in the model, despite an observed gradient of 2 to $3{ }^{\circ} \mathrm{C}$ in the firn column at NEEM, due to recent local warming in northwest Greenland (Carr 

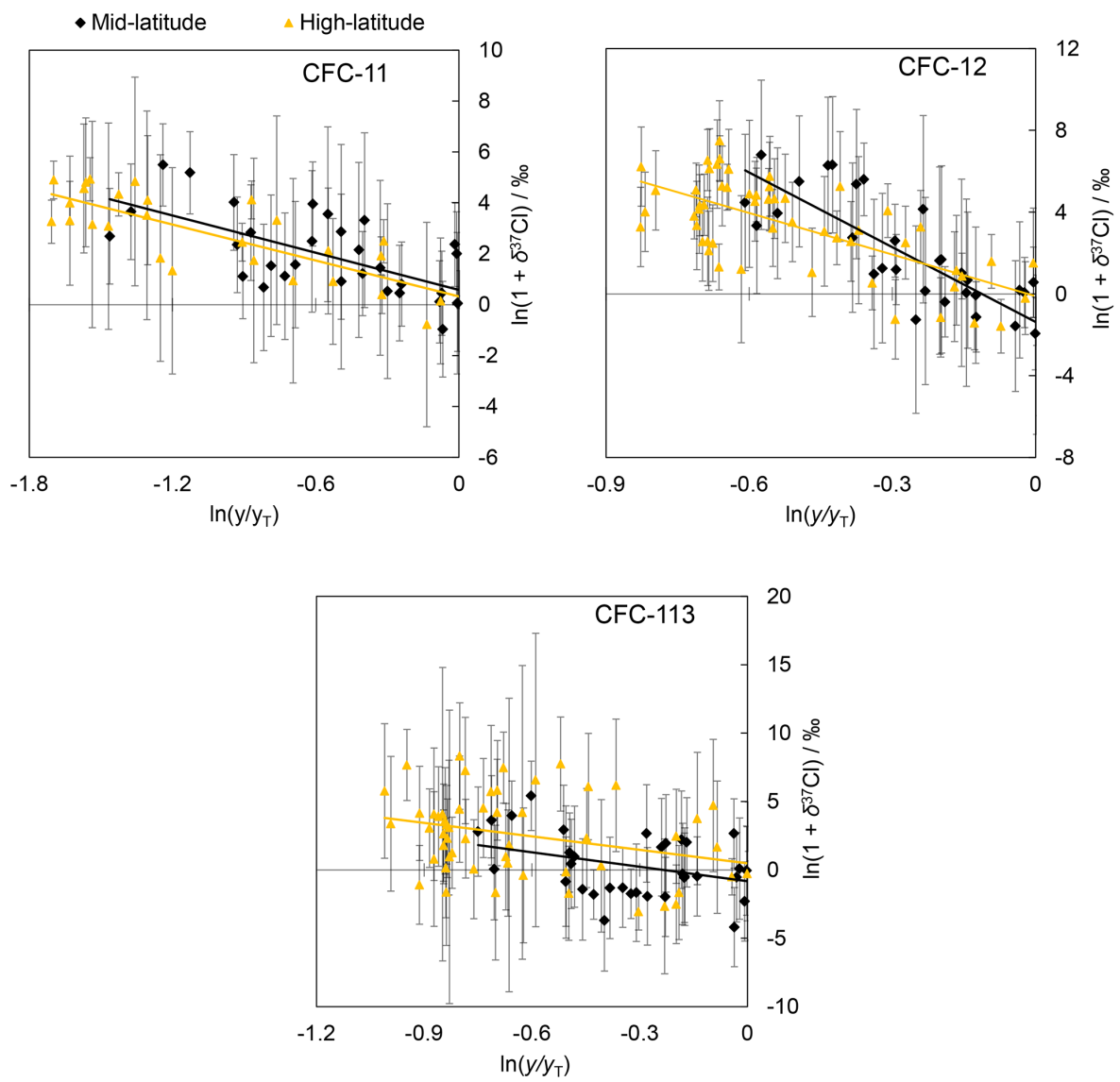

Figure 1. Rayleigh fractionation plots of CFC-11, CFC-12 and CFC-113 chlorine isotope signatures, derived from mid-latitude (black diamonds) and high-latitude (orange triangles) stratospheric samples. Trend lines correspond to apparent fractionations $\left(\varepsilon_{\text {app }}\right)$ of $-2.4(0.5)$ and $-2.3(0.4) \%$ (CFC-11), - 12.2 (1.6) and -6.8 (0.8)\%o (CFC-12) and -3.5 (1.5) and -3.3 (1.2)\%o (CFC-113) for mid- and high latitudes, respectively. The standard error of the gradient is quoted for $\varepsilon_{\text {app }}$ values. The average repeatability for individual samples was $\pm 2.3 \%$ (CFC-11), $\pm 2.4 \%$ (CFC-12) and $\pm 3.9 \%$ (CFC-113). $1 \sigma$ standard deviation error bars are shown and rejected measurements are not included.

et al., 2013). This is because although the thermal diffusion effect on the CFC mole fractions is on the order of $0.2 \%$ at NEEM, the effect on $\delta\left({ }^{37} \mathrm{Cl}\right)$ is estimated to be less than $0.02 \%$ (Leuenberger and Lang, 2002).

\section{Results and discussion}

\subsection{Stratospheric data}

After outlier correction (Sect. 2.2), a total of 31 and 28 (CFC$11), 33$ and 54 (CFC-12) and 36 and 54 (CFC-113) measurements remain, for samples collected in the mid- and highlatitude stratosphere, respectively.

Negative apparent isotope fractionations $\left(\varepsilon_{\text {app }}\right)$ have been calculated for all three species (Fig. 1). This indicates that sink reactions discriminate against heavier isotopes, in other words, the heavier isotopologue is broken down more slowly, causing the observed enrichment in ${ }^{37} \mathrm{Cl}$. Trend lines in Fig. 1 correspond to apparent fractionations $\left(\varepsilon_{\text {app }}\right)$ of $-2.4(0.5)$ and $-2.3(0.4) \%$ (CFC-11), $-12.2(1.6)$ and $-6.8(0.8) \%$ (CFC-12) and -3.5 (1.5) and -3.3 (1.2)\%o (CFC-113) for mid- and high latitudes, respectively. As the sampling point moves from mid- to high latitudes, the absolute CFC-12 $\varepsilon_{\text {app }}$ value decreases. This effect is qualitatively the same for $\mathrm{N}_{2} \mathrm{O}$ (Kaiser et al., 2006). CFC-11 and CFC-113 both show midand high-latitude $\varepsilon_{\text {app }}$ values that are indistinguishable within 1 standard deviation. It could be that the latitude dependence seen in CFC-12 and $\mathrm{N}_{2} \mathrm{O}$ also exists in these compounds, but is obscured by the size of analytical uncertainties, compared to the relatively small isotope changes being tracked.

Laube et al. (2010a) calculated the tropical CFC-12 $\varepsilon_{\text {app }}$ to be -12.1 (1.7)\%o, which agrees with the mid-latitude value of -12.2 (1.5)\%o presented here. Given the lower $\varepsilon_{\text {app }}$ value calculated from high-latitude samples, a difference between $\varepsilon_{\text {app }}$ values at mid-latitudes and the tropics might be expected. The relative difference between mid-latitude/tropical and polar $\varepsilon_{\text {app }}$ is much larger for CFC-12 than for $\mathrm{N}_{2} \mathrm{O}$. Due to the similar atmospheric lifetimes of CFC-12 and $\mathrm{N}_{2} \mathrm{O}$, this 


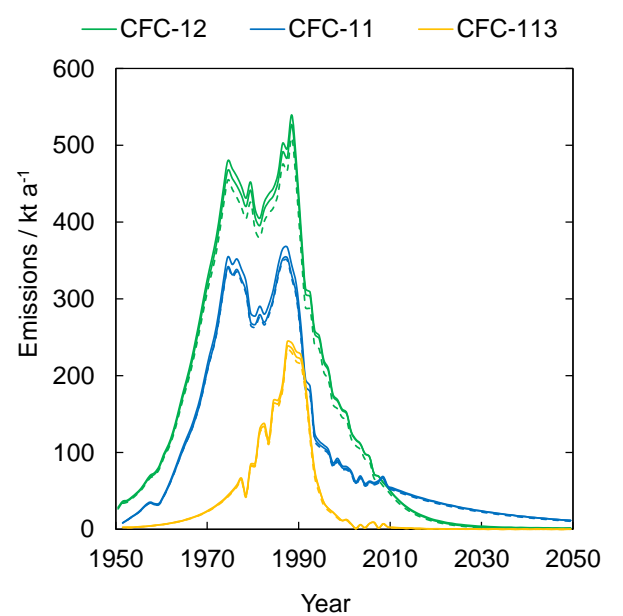

Figure 2. Emissions estimates for CFC-11 (blue), CFC-12 (green) and CFC-113 (orange), based on global tropospheric mole fractions (SPARC, 2013). Each species is represented by three lines. The two emissions estimates from this study (solid lines) are produced using the stratosphere-troposphere exchange flux calculations of Holton (1990) and Appenzeller et al. (1996), with the latter giving slightly higher emissions. These are compared to values from Velders and Daniel (2014) (dashed lines).

is unlikely to be due to dynamic effects as suggested for $\mathrm{N}_{2} \mathrm{O}$ (Kaiser et al., 2006) and is at present unexplained. In the absence of globally representative $\varepsilon_{\text {app }}$ values, we use the midlatitude values to project the tropospheric isotope $\delta$ changes over time.

\subsection{Emissions and transport modelling}

Based on historical and predicted atmospheric mole fractions (Velders and Daniel, 2014), our two-box approach estimates global emissions for CFC-11, CFC-12 and CFC-113 from 1950 to 2050. Figure 2 shows good agreement between these values and previously published estimates (Velders and Daniel, 2014). The proliferation of CFC production and consumption caused an initial sharp increase in emissions, followed by sustained high emissions during the 1970s and 1980s. The Montreal Protocol and its subsequent amendments ensured a significant reduction in CFC production, causing the concurrent decrease in emissions of all three species at the end of the 1980s.

Figure 3 shows how the tropospheric $\delta\left({ }^{37} \mathrm{Cl}\right)$ of these three compounds would have changed with time, assuming no source variations. From their first release until the present day, tropospheric CFC-11, CFC-12 and CFC-113 $\delta\left({ }^{37} \mathrm{Cl}\right)$ values are predicted to have increased by 1,3 and $1 \%$, respectively. Maximum rates of increase are predicted to have occurred since 1990, which coincide with the sharp reduction in CFC emissions due to the introduction of legislation phasing out their production and consumption (Montzka et al., 2011). A drop in the anthropogenic input means that the ex- isting atmospheric pool will become increasingly enriched, as demonstrated by the predicted acceleration of tropospheric $\delta\left({ }^{37} \mathrm{Cl}\right)$ increase after 1990.

The shading in Fig. 3 represents the uncertainty envelope. Approximately equal contributions to the uncertainty arise from (1) the differing reference interfaces for stratospheretroposphere exchange used by Holton (1990) and Appenzeller et al. (1996), namely the $100 \mathrm{mbar}$ and the $380 \mathrm{~K}$ isentrope, respectively; (2) the $1 \sigma$ uncertainty in $\varepsilon_{\text {app }}$ values; (3) the range of "most likely" lifetime values from SPARC (2013).

\subsection{Tropospheric data}

Using the GC-MS instrument discussed in this work, Laube et al. (2010a) verified that their isotope ratio measurements were not biased by the response behaviour of the analytical system. They measured CFC-12 to a minimum of $77 \mathrm{pmol} \mathrm{mol}^{-1}$. The present study covers a wider range of CFC-12 mole fractions and also includes CFC-11 and CFC113 , meaning that a more extensive effort was necessary to remove the possibility of a bias in this work (details in the Supplement).

From three independent data sets, a total of 44 (CFC-11), $74(\mathrm{CFC}-12)$ and $48(\mathrm{CFC}-113) \delta\left({ }^{37} \mathrm{Cl}\right)$ measurements are presented, covering the last 60,50 and 45 years, respectively (Fig. 3). In general, there is good agreement between the Cape Grim and firn air measurements. This agreement is in line with expectations from these well-mixed gases. The predicted trends for all three species are small (Fig. 3), with the largest isotope changes expected to have occurred in the last 2 decades. From 1970 to the present day, the projected changes can be accounted for within analytical uncertainties (Fig. 3). This means that for these three CFCs, our observations are consistent with an isotopically invariant source signature, but the high measurement uncertainty does not allow us to preclude the possibility that it has changed over time. Despite the noted parallels in atmospheric chemical behaviour between CFC-12 and $\mathrm{N}_{2} \mathrm{O}$, their atmospheric isotope $\delta$ histories differ because $\mathrm{N}_{2} \mathrm{O}$ has been present in the atmosphere for at least 800000 years longer than CFC-12 (Spahni et al., 2005; Schilt et al., 2010). When anthropogenic emissions began, atmospheric $\mathrm{N}_{2} \mathrm{O}$ isotope $\delta$ were perturbed from a near steady-state source-sink system, whereas the industrial release of CFC-12 was not preceded by any atmospheric burden. This has caused $\delta\left({ }^{15} \mathrm{~N}, \mathrm{~N}_{2} \mathrm{O}\right)$ and $\delta\left({ }^{18} \mathrm{O}\right.$, $\mathrm{N}_{2} \mathrm{O}$ ) to decrease over the last century (Röckmann et al., 2003), while $\delta\left({ }^{37} \mathrm{Cl}, \mathrm{CFC}-12\right)$ is predicted to have increased slightly (Fig. 3).

Before 1970, there were two (CFC-11), one (CFC-12) and two (CFC-113) measurements between 5 and $10 \%$ higher than expected, which could represent source $\delta\left({ }^{37} \mathrm{Cl}\right)$ changes. Emissions of these gases earlier in the record represent a larger proportion of the total atmospheric load, meaning that our measurements are more sensitive to source $\delta\left({ }^{37} \mathrm{Cl}\right)$ 

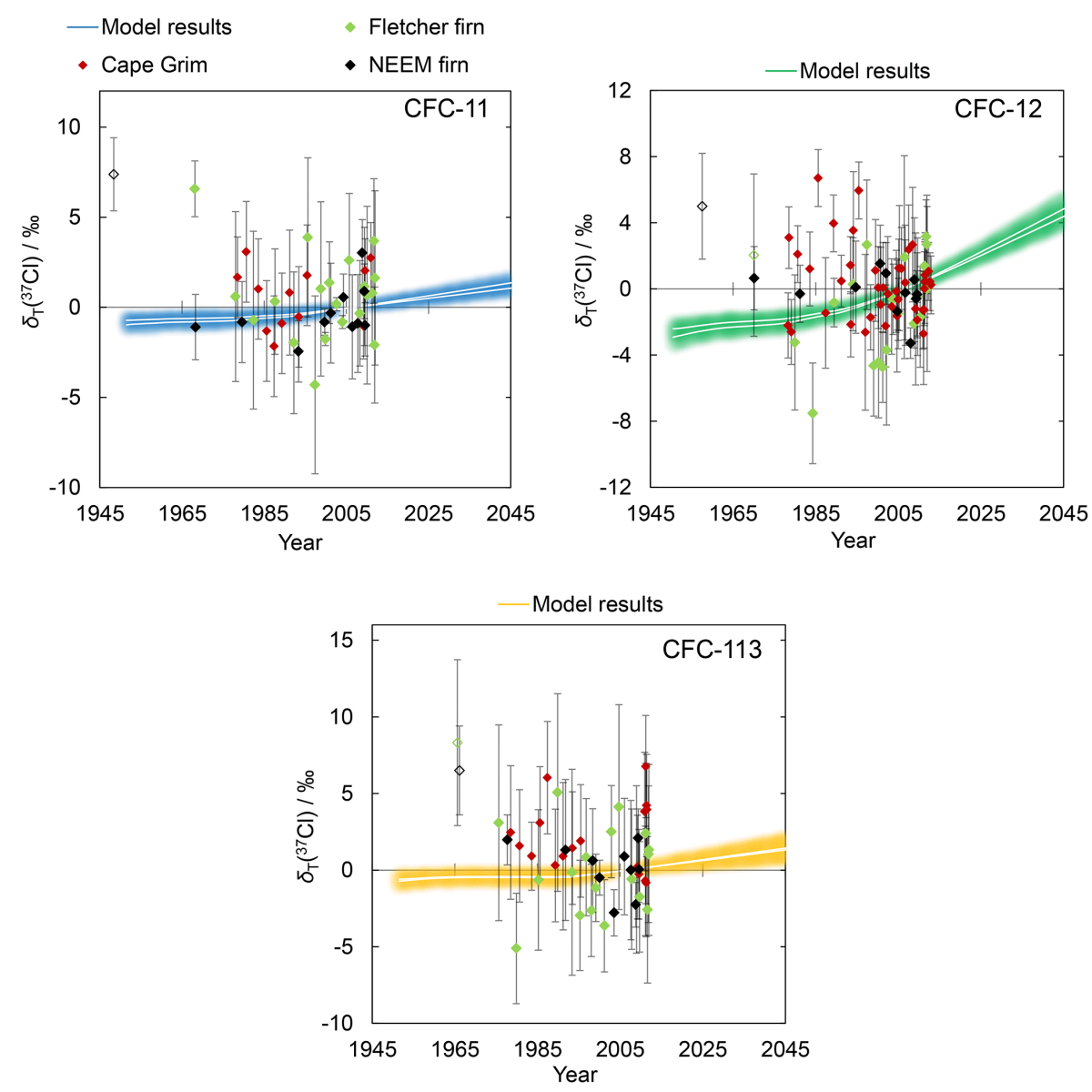

Figure 3. Tropospheric $\delta\left({ }^{37} \mathrm{Cl}\right)$ measurements, compared to model predictions. Black diamonds (NEEM firn air), green diamonds (Fletcher Promontory firn air) and red diamonds (Cape Grim air archive) represent the tropospheric chlorine isotope history of CFC-11, CFC-12 and CFC-113. The average repeatability for individual samples was $\pm 2.7 \%$ (CFC-11), $\pm 2.7 \%$ (CFC-12) and $\pm 3.8 \%$ (CFC-113). $1 \sigma$ standard deviation error bars are shown. Open symbols indicate that the measurement was subject to a small correction, based on instrumental nonlinearities (see Supplement). White trend lines represent model estimates of the temporal evolution of $\delta_{\mathrm{T}}\left({ }^{37} \mathrm{Cl}\right)$ values. Two lines are displayed per species, one for each stratosphere-troposphere exchange flux estimate (Holton, 1990; Appenzeller et al., 1996). Blue (CFC-11), green (CFC-12) and orange (CFC-113) shading indicates the model uncertainty envelopes. These uncertainties are based on two independent sources of error: (1) the $1 \sigma$ uncertainty in $\varepsilon_{\text {app }}$ values; (2) the range of most likely lifetime values from SPARC (2013). All $\delta$ values are relative to an air sample collected in 2006 and the model output has been adjusted so that it passes through $0 \%$ at 2006 .

changes at this time. As the oldest samples, these five measurements contain the lowest CFC mole fractions, producing higher-than-average analytical uncertainties. Also, a small correction was applied to four of them, introducing an additional error (details in the Supplement). The limited number and precision of these measurements make it premature at this stage to report a source $\delta\left({ }^{37} \mathrm{Cl}\right)$ change in these gases.

Zuiderweg et al. (2013) describe how the manufacturing processes used to synthesise chlorofluorocarbons have altered through industrial advances in the 20th century. The most significant change occurred in the production of the main feedstock $\left(\mathrm{CCl}_{4}\right)$. Traditionally it was synthesised through the chlorination of $\mathrm{CS}_{2}$, but in the last 50 years $\mathrm{CH}_{4}$ has been used in this chlorination. Zuiderweg et al. (2013) cite these methodological changes as the most likely cause of the significant ${ }^{13} \mathrm{C}$ enrichment of $\mathrm{CFC}-12$, but there is no direct evidence to confirm that changes in production processes have changed the isotope signature of the resultant CFCs.

\section{Conclusions}

Samples from the Cape Grim air archive (Tasmania, 19782010) and firn air samples from NEEM (Greenland) and Fletcher Promontory (Antarctica) have been used to infer an atmospheric history of chlorine isotopes in the three most abundant CFCs. These measurements cover the last 60 (CFC11), 50 (CFC-12) and 45 (CFC-113) years. All three species are isotopically enriched in the stratosphere by destruction processes, leading to negative apparent isotope fractiona- 
tions $\left(\varepsilon_{\text {app }}\right)$. This measured stratospheric isotope dependence and an assumed constant source $\delta\left({ }^{37} \mathrm{Cl}\right)$ were used to reconstruct the long-term changes in their tropospheric isotope signatures. The predicted trends are small due to the long atmospheric lifetimes of the species and can largely be accounted for in our tropospheric measurements, although the high measurement uncertainty does not allow us to preclude the possibility that the average emission isotope $\delta$ has changed over time. Across all species, five pre-1970 $\delta\left({ }^{37} \mathrm{Cl}\right)$ values are higher than predicted. A source $\delta\left({ }^{37} \mathrm{Cl}\right)$ change could explain this offset, but at present the available data are too limited in number and precision to confirm this.

Laube et al. (2010a) suggested that a more complete understanding of CFC-12 chlorine isotope changes could lead to better $\mathrm{O}_{3}$ recovery predictions and the identification of individual sources from their isotope signatures. Given the significant CFC-12 carbon isotope changes reported by Zuiderweg et al. (2013), it seemed likely that a characterisation of CFC chlorine isotopes would help to achieve these goals. However, this study reveals only small long-term changes, with current analytical precisions not allowing for such an analysis. Measuring CFCs at their point of release (e.g. old refrigeration units) and improving measurement precision would help confirm whether there have been any sourcedriven chlorine isotope changes.

The instrument used in this work has the capacity to measure chlorine isotope ratios in other trace gases (e.g. CFC115). Also, less abundant fragment ions can be measured (e.g. fragments containing ${ }^{13} \mathrm{C}$ ), extending this pool of isotopic information to stable carbon isotopes. Finally, the high sensitivity of this instrument opens up the possibility of isotopically analysing the small air samples extracted from ice cores. Therefore, gases with both anthropogenic and natural sources can be investigated (e.g. carbonyl sulfide and methyl chloride).

\section{The Supplement related to this article is available online at doi:10.5194/acp-15-6867-2015-supplement.}

Acknowledgements. We thank the UK Natural Environment Research Council (grant nos. NE/K500896/1, NE/F015585/1 \& $\mathrm{NE} / \mathrm{I021918/1}$, the National Centre for Atmospheric Science) and the European Commission (INFRA-2011-1.1.11-284274) for funding. We thank the staff at the Cape Grim station and at CSIRO GASLAB Aspendale for collecting and maintaining the Cape Grim air archive and preparing the UEA flasks and sub-samples. We also acknowledge CSIRO and the Bureau of Meteorology for funding these activities. NEEM is directed and organised by the Centre for Ice and Climate at the Niels Bohr Institute and US NSF, Office of Polar Programs. It is supported by funding agencies and institutions in Belgium (FNRS-CFB and FWO), Canada (GSC), China (CAS), Denmark (FIST), France (IPEV, CNRS/INSU, CEA and ANR), Germany (AWI), Iceland (RannIs),
Japan (NIPR), Korea (KOPRI), the Netherlands (NWO/ALW), Sweden (VR), Switzerland (SNF), United Kingdom (NERC) and the USA (US NSF, Office of Polar Programs). The Geophysica flights from Oberpfaffenhofen were funded by ESA under the PremieEx project and by Forschungszentrum Jülich. The Fletcher air pumping campaign was made possible with the support of BAS operations and logistics and funded by the Natural Environment Research Council. The Geophysica flights from Kiruna were funded by the European Commission as part of the FP7 project RECONCILE (grant no. RECONCILE-226365-FP7-ENV-2008-1). Air sampling during these campaigns was funded by the Dutch Science Foundation (NWO, grant no. 865.07.001). In addition we are grateful for contributions from Michel Bolder and the Geophysica team (sample collection and campaign organisation).

Edited by: J. B. Burkholder

\section{References}

Appenzeller, C., Holton, J. R., and Rosenlof, K. H.: Seasonal variation of mass transport across the tropopause, J. Geophys. Res., 101, 15071-15078, doi:10.1029/96JD00821, 1996.

Batenburg, A. M., Schuck, T. J., Baker, A. K., Zahn, A., Brenninkmeijer, C. A. M., and Röckmann, T.: The stable isotopic composition of molecular hydrogen in the tropopause region probed by the CARIBIC aircraft, Atmos. Chem. Phys., 12, 46334646, doi:10.5194/acp-12-4633-2012, 2012.

Bernard, S., Röckmann, T., Kaiser, J., Barnola, J.-M., Fischer, H., Blunier, T., and Chappellaz, J.: Constraints on $\mathrm{N}_{2} \mathrm{O}$ budget changes since pre-industrial time from new firn air and ice core isotope measurements, Atmos. Chem. Phys., 6, 493-503, doi:10.5194/acp-6-493-2006, 2006.

Brenninkmeijer, C. A. M., Janssen, C., Kaiser, J., Röckmann, T., Rhee, T. S., and Assonov, S. S.: Isotope effects in the chemistry of atmospheric trace gases, Chem. Rev., 103, 5125-5162, doi:10.1021/cr020644k, 2003.

Buizert, C., Martinerie, P., Petrenko, V. V., Severinghaus, J. P., Trudinger, C. M., Witrant, E., Rosen, J. L., Orsi, A. J., Rubino, M., Etheridge, D. M., Steele, L. P., Hogan, C., Laube, J. C., Sturges, W. T., Levchenko, V. A., Smith, A. M., Levin, I., Conway, T. J., Dlugokencky, E. J., Lang, P. M., Kawamura, K., Jenk, T. M., White, J. W. C., Sowers, T., Schwander, J., and Blunier, T.: Gas transport in firn: multiple-tracer characterisation and model intercomparison for NEEM, Northern Greenland, Atmos. Chem. Phys., 12, 4259-4277, doi:10.5194/acp-12-4259-2012, 2012.

Butler, J. H., Battle, M., Bender, M. L., Monzka, S. A., Clarke, A. D., Saltzman, E. S., Sucher, C. M., Severinghaus, J. P., and Elkins, J. W.: A record of atmospheric halocarbons during the twentieth century from polar firn air, Nature, 399, 749-755, doi:10.1038/21586, 1999.

Carr, J. R., Vieli, A., and Stokes, C.: Influence of sea ice decline, atmospheric warming, and glacier width on marine-terminating outlet glacier behavior in northwest Greenland at seasonal to interannual timescales, J. Geophys. Res.-Earth, 118, 1210-1226, doi:10.1002/jgrf.20088, 2013.

Etheridge, D. M., Steele, L. P., Francey, R. J., and Langenfelds, R. L.: Atmospheric methane between 1000 A.D. and present: Evidence of anthropogenic emissions and climatic variability, 
J. Geophys. Res., 103, 15979-15993, doi:10.1029/98JD00923, 1998.

Farman, J. C., Gardiner, B. G., and Shanklin, J. D.: Large losses of total ozone in Antarctica reveal seasonal $\mathrm{ClO}_{x} / \mathrm{NO}_{x}$ interaction, Nature, 315, 207-210, doi:10.1038/315207a0, 1985.

Francey, R. J., Allison, C. E., Etheridge, D. M., Trudinger, C. M., Enting, I. G., Leuenberger, M., Langenfelds, R. L., Michel, E., and Steele, L. P.: A 1000-year high precision record of $\delta^{13} \mathrm{C}$ in atmospheric $\mathrm{CO}_{2}$, Tellus B, 51, 170-193, doi:10.1034/j.16000889.1999.t01-1-00005.x, 1999.

Goldstein, A. H. and Shaw, S. L.: Isotopes of volatile organic compounds: an emerging approach for studying atmospheric budgets and chemistry, Chem. Rev., 103, 5025-5048, doi:10.1021/cr0206566, 2003.

Holton, J. R.: On the global exchange of mass between the stratosphere and troposphere, J. Atmos. Sci., 47, 392-395, doi:10.1175/1520-0469(1990)047<0392:OTGEOM>2.0.CO;2, 1990.

Ishijima, K., Sugawara, S., Kawamura, K., Hashida, G., Morimoto, S., Murayama, S., Aoki, S., and Nakazawa, T.: Temporal variations of the atmospheric nitrous oxide concentration and its $\delta^{15} \mathrm{~N}$ and $\delta^{18} \mathrm{O}$ for the latter half of the 20th century reconstructed from firn air analyses, J. Geophys. Res.-Atmos., 112, D03305, doi:10.1029/2006JD007208, 2007.

Kaiser, J.: Stable isotope investigations of atmospheric nitrous oxide, available at: http://archimed.uni-mainz.de/pub/2003/0004/ (last access: 4 June 2015), PhD thesis, Johannes GutenbergUniversität, Mainz, 2002.

Kaiser, J., Engel, A., Borchers, R., and Röckmann, T.: Probing stratospheric transport and chemistry with new balloon and aircraft observations of the meridional and vertical $\mathrm{N}_{2} \mathrm{O}$ isotope distribution, Atmos. Chem. Phys., 6, 3535-3556, doi:10.5194/acp6-3535-2006, 2006.

Langenfelds, R. J., Fraser, P. J., Francey, R. J., Steele, L. P., Porter, L. W., and Allison, C. E.: The Cape Grim air archive: The first seventeen years, in: Baseline 94-95, edited by: Francey, R. J., Dick, A. L., and Derek, N., 53-70, Bur. Meteorol. and CSIRO Atmos. Res., Melbourne, Victoria, Australia, 1996.

Laube, J. C., Kaiser, J., Sturges, W. T., Bönisch, H., and Engel, A.: Chlorine Isotope Fractionation in the Stratosphere, Science, 329, 1167, doi:10.1126/science.1191809, 2010a.

Laube, J. C., Martinerie, P., Witrant, E., Blunier, T., Schwander, J., Brenninkmeijer, C. A. M., Schuck, T. J., Bolder, M., Röckmann, T., van der Veen, C., Bönisch, H., Engel, A., Mills, G. P., Newland, M. J., Oram, D. E., Reeves, C. E., and Sturges, W. T.: Accelerating growth of HFC-227ea (1,1,1,2,3,3,3-heptafluoropropane) in the atmosphere, Atmos. Chem. Phys., 10, 5903-5910, doi:10.5194/acp-10-5903-2010, 2010b.

Laube, J. C., Newland, M. J., Hogan, C., Brenninkmeijer, C. A. M., Fraser, P. J., Martinerie, P., Oram, D. E., Reeves, C. E., Röckmann, T., Schwander, J., Witrant, E., and Sturges, W. T.: Newly detected ozone-depleting substances in the atmosphere, Nat. Geosci., 7, 266-269, doi:10.1038/ngeo2109, 2014.

Leuenberger, M. and Lang, C.: Thermal diffusion: An important aspect in studies of static air columns such as firn air, sand dunes, and soil air, in: Isotope aided studies of atmospheric carbon dioxide and other greenhouse gases - Phase II, IAEA, Vienna, 2002.
Martinerie, P., Nourtier-Mazauric, E., Barnola, J.-M., Sturges, W. T., Worton, D. R., Atlas, E., Gohar, L. K., Shine, K. P., and Brasseur, G. P.: Long-lived halocarbon trends and budgets from atmospheric chemistry modelling constrained with measurements in polar firn, Atmos. Chem. Phys., 9, 3911-3934, doi:10.5194/acp-9-3911-2009, 2009.

McCarthy, M. C., Connell, P., and Boering, K. A.: Isotopic fractionation of methane in the stratosphere and its effect on free tropospheric isotopic compositions, Geophys. Res. Lett., 28, 3657 3660, doi:10.1029/2001GL013159, 2001.

Molina, M. J. and Rowland, F. S.: Stratospheric sink for chlorofluoromethanes: chlorine atomc-atalysed destruction of ozone, Nature, 249, 810-812, doi:10.1038/249810a0, 1974.

Montzka, S. A., Reimann, S., Engel, A., Krueger, K., O’Doherty, S., and Sturges, W. T.: Ozone-depleting substances (ODSs) and related chemicals, in: Scientific Assessment of Ozone Depletion, Chapter 1, World Meteorological Organization, Geneva, 2011.

Mulvaney, R., Triest, J., and Alemany, O.: The James Ross Island and the Fletcher Promontory ice-core drilling projects, Ann. Glaciol., 55, 179-188, doi:10.3189/2014AoG68A044, 2014.

NEEM Community Members: Eemian interglacial reconstructed from a Greenland folded ice core, Nature, 493, 489-494, doi:10.1038/nature11789, 2013.

Nevison, C. D., Keeling, R. F., Weiss, R. F., Popp, B. N., Fraser, P. J., Porter, L. W., and Hess, P. G.: Southern Ocean ventilation inferred from seasonal cycles of atmospheric $\mathrm{N}_{2} \mathrm{O}$ and $\mathrm{O}_{2} / \mathrm{N}_{2}$ at Cape Grim, Tasmania, Tellus B, 57, 218-229, doi:10.1111/j.1600-0889.2005.00143.x, 2005.

Nevison, C. D., Dlugokencky, E., Dutton, G., Elkins, J. W., Fraser, P., Hall, B., Krummel, P. B., Langenfelds, R. L., O'Doherty, S., Prinn, R. G., Steele, L. P., and Weiss, R. F.: Exploring causes of interannual variability in the seasonal cycles of tropospheric nitrous oxide, Atmos. Chem. Phys., 11, 3713-3730, doi:10.5194/acp-11-3713-2011, 2011.

Park, S., Croteau, P., Boering, K. A., Etheridge, D. M., Ferretti, D., Fraser, P. J., Kim, K. R., Krummel, P. B., Langenfelds, R. L., van Ommen, T. D., Steele, L. P., and Trudinger, C. M.: Trends and seasonal cycles in the isotopic composition of nitrous oxide since 1940, Nat. Geosci., 5, 261-265, doi:10.1038/NGEO1421, 2012.

Redeker, K. R., Davis, S., and Kalin, R. M.: Isotope values of atmospheric halocarbons and hydrocarbons from Irish urban, rural, and marine locations, J. Geophys. Res., 112, D16307, doi:10.1029/2006JD007784, 2007.

Röckmann, T. and Levin, I.: High-precision determination of the changing isotopic composition of atmospheric $\mathrm{N}_{2} \mathrm{O}$ from 1990-2002, J. Geophys. Res.-Atmos., 110, D21304, doi:10.1029/2005JD006066, 2005.

Röckmann, T., Kaiser, J., and Brenninkmeijer, C. A. M.: The isotopic fingerprint of the pre-industrial and the anthropogenic $\mathrm{N}_{2} \mathrm{O}$ source, Atmos. Chem. Phys., 3, 315-323, doi:10.5194/acp-3315-2003, 2003

Rubino, M., Etheridge, D. M., Trudinger, C. M., Allison, C. E., Battle, M. O., Langenfelds, R. L., Steele, L. P., Curran, M., Bender M., White, J. W. C., Jenk, T. M., Blunier, T., and Francey, R. J.: A revised 1000 year atmospheric $\delta^{13} \mathrm{C}-\mathrm{CO}_{2}$ record from Law Dome and South Pole, Antarctica, J. Geophys. Res.-Atmos., 118, 8482-8499, doi:10.1002/jgrd.50668, 2013. 
Schilt, A., Baumgartner, M., Blunier, T., Schwander, J., Spahni, R., Fischer, H., and Stocker, T. F.: Glacial-interglacial and millennial-scale variations in the atmospheric nitrous oxide concentration during the last 800,000 years, Quaternary Sci. Rev., 29, 182-192, doi:10.1016/j.quascirev.2009.03.011, 2010.

Schwander, J., Barnola, J. M., Andrie, C., Leuenberger, M., Ludin, A., Raynaud, D., and Stauffer, B.: The age of the air in the firn and the ice at Summit, Greenland, J. Geophys. Res.-Atmos., 98, 2831-2838, doi:10.1029/92JD02383, 1993.

Sowers, T., Rodebaugh, A., Yoshida, N., and Toyoda, S.: Extending records of the isotopic composition of the atmospheric $\mathrm{N}_{2} \mathrm{O}$ back to $1800 \mathrm{AD}$ from air trapped in snow at the South Pole and the Greenland Ice Sheet Project II ice core, Global Biogeochem. Cy., 16, 1129, doi:10.1029/2002GB001911, 2002.

Spahni, R., Chappellaz, J., Stocker, T. F., Loulergue, L., Hausammann, G., Kawamura, K., Flückiger, J., Schwander, J., Raynaud, D., Masson-Delmotte, V., and Jouzel, J.: Atmospheric methane and nitrous oxide of the late pleistocene from Antarctic ice cores, Science, 310, 1317-1321, doi:10.1126/science.1120132, 2005.

SPARC: Report on the lifetimes of stratospheric ozone-depleting substances, their replacements, and related species, edited by: Ko, M., Newman, P., Reimann, S., and Strahan, S., SPARC Report No. 6, WCRP-15, Zurich, Switzerland, 2013.

Sturges, W. T., Oram, D. E., Laube, J. C., Reeves, C. E., Newland, M. J., Hogan, C., Martinerie, P., Witrant, E., Brenninkmeijer, C. A. M., Schuck, T. J., and Fraser, P. J.: Emissions halted of the potent greenhouse gas $\mathrm{SF}_{5} \mathrm{CF}_{3}$, Atmos. Chem. Phys., 12, 36533658, doi:10.5194/acp-12-3653-2012, 2012.

Sturrock, G. A., Etheridge, D. M., Trudinger, C. M., Fraser, P. J., and Smith, A. M.: Atmospheric histories of halocarbons from analysis of Antarctic firn air: Major Montreal Protocol species, J. Geophys. Res.-Atmos., 107, 4765, doi:10.1029/2002JD002548, 2002.

Trenberth, K. E. and Guillemot, C. J.: The total mass of the atmosphere, J. Geophys. Res.-Atmos., 99, 23079-23088, doi:10.1029/94JD02043, 1994.

Velders, G. J. M. and Daniel, J. S.: Uncertainty analysis of projections of ozone-depleting substances: mixing ratios, EESC, ODPs, and GWPs, Atmos. Chem. Phys., 14, 2757-2776, doi:10.5194/acp-14-2757-2014, 2014.

Volk, C. M., Elkins, J. W., Fahey, D. W., Sutton, G. S., Gilligan, J. M., Loewenstein, M., Podolske, J. R., Chan, K. R., and Gunson, M. R.: Evaluation of source gas lifetimes from stratospheric observations, J. Geophys. Res., 102, 25543-25564, 1997. von Hobe, M., Bekki, S., Borrmann, S., Cairo, F., D’Amato, F., Di Donfrancesco, G., Dörnbrack, A., Ebersoldt, A., Ebert, M., Emde, C., Engel, I., Ern, M., Frey, W., Genco, S., Griessbach, S., Grooß, J.-U., Gulde, T., Günther, G., Hösen, E., Hoffmann, L., Homonnai, V., Hoyle, C. R., Isaksen, I. S. A., Jackson, D. R., Jánosi, I. M., Jones, R. L., Kandler, K., Kalicinsky, C., Keil, A., Khaykin, S. M., Khosrawi, F., Kivi, R., Kuttippurath, J., Laube, J. C., Lefèvre, F., Lehmann, R., Ludmann, S., Luo, B. P., Marchand, M., Meyer, J., Mitev, V., Molleker, S., Müller, R., Oelhaf, H., Olschewski, F., Orsolini, Y., Peter, T., Pfeilsticker, K., Piesch, C., Pitts, M. C., Poole, L. R., Pope, F. D., Ravegnani, F., Rex, M., Riese, M., Röckmann, T., Rognerud, B., Roiger, A., Rolf, C., Santee, M. L., Scheibe, M., Schiller, C., Schlager, H., Siciliani de Cumis, M., Sitnikov, N., Søvde, O. A., Spang, R., Spelten, N., Stordal, F., Sumińska-Ebersoldt, O., Ulanovski, A., Ungermann, J., Viciani, S., Volk, C. M., vom Scheidt, M., von der Gathen, P., Walker, K., Wegner, T., Weigel, R., Weinbruch, S., Wetzel, G., Wienhold, F. G., Wohltmann, I., Woiwode, W., Young, I. A. K., Yushkov, V., Zobrist, B., and Stroh, F.: Reconciliation of essential process parameters for an enhanced predictability of Arctic stratospheric ozone loss and its climate interactions (RECONCILE): activities and results, Atmos. Chem. Phys., 13, 92339268, doi:10.5194/acp-13-9233-2013, 2013.

Witrant, E. and Martinerie, P.: Input Estimation from Sparse Measurements in LPV Systems and Isotopic Ratios in Polar Firns, in: Proc. of the IFAC Joint Symposium on SSSC, TDS and FDA, 659-664, The International Federation of Automatic Control, Grenoble, France, doi:10.3182/20130204-3-FR2033.00201, 2013.

Witrant, E., Martinerie, P., Hogan, C., Laube, J. C., Kawamura, K., Capron, E., Montzka, S. A., Dlugokencky, E. J., Etheridge, D., Blunier, T., and Sturges, W. T.: A new multi-gas constrained model of trace gas non-homogeneous transport in firn: evaluation and behaviour at eleven polar sites, Atmos. Chem. Phys., 12, 11465-11483, doi:10.5194/acp-12-11465-2012, 2012.

Yoshida, N. and Toyoda, S.: Constraining the atmospheric $\mathrm{N}_{2} \mathrm{O}$ budget from intramolecular site preference in $\mathrm{N}_{2} \mathrm{O}$ isotopomers, Nature, 405, 330-334, 6784, doi:10.1038/35012558, 2000.

Zuiderweg, A., Kaiser, J., Laube, J. C., Röckmann, T., and Holzinger, R.: Stable carbon isotope fractionation in the UV photolysis of CFC-11 and CFC-12, Atmos. Chem. Phys., 12, 43794385, doi:10.5194/acp-12-4379-2012, 2012.

Zuiderweg, A., Holzinger, R., Martinerie, P., Schneider, R., Kaiser, J., Witrant, E., Etheridge, D., Petrenko, V., Blunier, T., and Röckmann, T.: Extreme ${ }^{13} \mathrm{C}$ depletion of $\mathrm{CCl}_{2} \mathrm{~F}_{2}$ in firn air samples from NEEM, Greenland, Atmos. Chem. Phys., 13, 599-609, doi:10.5194/acp-13-599-2013, 2013. 